\title{
Effects of relaxin, pregnancy and parturition on collagen metabolism in the rat pubic symphysis
}

\author{
C S Samuel ${ }^{1,2}$, J P Coghlan ${ }^{1}$ and J F Bateman ${ }^{2}$ \\ ${ }^{1}$ Howard Florey Institute of Experimental Physiology and Medicine and ${ }^{2}$ Orthopaedic Molecular Biology Research Unit, Department of Paediatrics, \\ University of Melbourne, Parkville 3052, Australia \\ (Requests for offprints should be addressed to J F Bateman, Orthopaedic Molecular Biology Research Unit, Department of Paediatrics, \\ University of Melbourne, Royal Children's Hospital, Parkville, 3052, Australia)
}

\begin{abstract}
The aim of this study was to examine the changes in collagen metabolism that occur during pregnancy and parturition and upon relaxin administration to the rat pubic symphysial interpubic tissue. Pubic symphyses were collected from non-pregnant, and intact and ovariectomised pregnant Sprague-Dawley rats at days 15, 18 and 21 of pregnancy as well as during and after delivery, and analysed for collagen content and solubility. SDS-PAGE was used to determine collagen composition. During pregnancy and particularly during birth, there was a significant reduction in both the tissue wet $(57 \pm 3 \%)$ and dry $(43 \pm 3 \%)$ weight $(n=7)$, which coincided with a significant increase in water content (to $80 \%$ ) and was attributed to a significant $(P<0.05)$ reduction in overall tissue collagen content (by $47 \pm 2 \%)$. This resulted in both soluble (10\%) and insoluble
\end{abstract}

(90\%) collagen levels being reduced, but gel electrophoresis demonstrated the presence of types I, II and V collagen in all samples. Western blot analysis confirmed the presence of type II collagen throughout pregnancy, confirming that the rat pubic symphysis remained a fibrocartilaginous tissue throughout gestation. In the absence of the ovaries and hence relaxin, tissue collagen content and solubility were not significantly different from control measurements. However, tissues of ovariectomised animals treated with oestrogen and progesterone (pellets) and relaxin (injection) contained collagen levels that mimicked those of late pregnancy and parturition. These results suggest that relaxin plays an important role in regulating collagen catabolism during gestation in the rat.

Journal of Endocrinology (1998) 159, 117-125

\section{Introduction}

Safe delivery of the young requires the pelvis, in particular the pubic symphysis, to undergo a number of hormonally facilitated structural modifications during pregnancy (Sherwood 1994). In several mammalian species (guineapig, human, mouse) the pubic symphysis is initially transformed from hyaline cartilage into fibrocartilage and eventually into an interpubic ligament during pregnancy and upon the addition of the reproductive hormones oestrogen and relaxin (Steinetz et al. 1965, 1983). While rat interpubic tissue remains fibrocartilaginous (Ruth 1932, Crelin \& Brightman 1957), previous work has shown that the addition of relaxin to the non-pregnant rat (Samuel et al. 1996) has analogous effects to those described in the mouse and human interpubic ligament (Hall 1956, Steinetz et al. 1965, 1983). The administration of purified synthetic relaxin to non-pregnant rats had a potent effect on collagen metabolism in the interpubic tissue, significantly increasing the length and weight while markedly decreasing collagen content, suggesting that the effects of relaxin on the pubic symphysis were independent of the tissue or species type.
Collagens make up a large family of glycoproteins with at least 19 molecular forms (Prockop \& Kivirriko 1995, Bateman et al. 1996), and are most abundant in the extracellular matrix of connective tissues. The mammalian reproductive tract is composed of a spectrum of collagen types including fibril-forming (types I, II, III, V), fibrilassociated (types IX, XI, XII, XIV), basement membrane (type IV), microfibrillar (type VI) and anchoring fibril (type VII) collagens. While many investigators have studied collagen in the mammalian pubic symphysis (Crelin \& Brightman 1957, Weiss et al. 1979), to date, the only study that has investigated the types of collagen present in the interpubic tissue is our previous one, which identified types I, II and V collagen in untreated and hormonally treated rat pubic symphyses (Samuel et al. 1996). However, the composition of the tissue during gestation and the changes that may occur leading to delivery of the young are yet to be determined.

The ability to regulate the amount and types of collagen in these tissues would have a profound effect on tissue structure and function, which would be crucial in growth and tissue repair processes such as those associated with pregnancy and parturition. Even subtle alterations to 
collagen composition may have dramatic implications with respect to the structural properties of the pelvic girdle and reproductive tract, whereby tissues may undergo conformational changes involving a turnover of specific collagen types to be able to accommodate delivery.

Relaxin is a polypeptide hormone which has been found in increased quantities in the serum during pregnancy in numerous mammalian species (Schwabe et al. 1978, Sherwood et al. 1980, 1993). The hormone has a number of potential biological functions and is thought to play a significant role in remodelling connective tissue in the pubic symphysis (Weiss et al. 1979, Samuel et al. 1996) and cervix (Downing \& Sherwood 1986) in preparation for parturition. The corpora lutea of pregnant rats are thought to be primarily responsible for producing and secreting relaxin into the peripheral circulation during the second half of the 22-23 day gestational period (Anderson et al. 1975, Anderson \& Long 1978, Golos et al. 1984). The elevation of relaxin levels in rat peripheral serum during late gestation (Sherwood \& Crnekovic 1979, Sherwood et al. 1980), which coincides, albeit temporarily, with a significant decline in serum progesterone levels, has been suggested to be necessary for delivery to occur (Sherwood et al. 1993).

The purpose of this study was to determine the changes in collagen content, solubility and composition that occur in the rat pubic symphysis over the later stages of pregnancy and parturition as compared with non-pregnant tissue measurements and to investigate the influence of the presence or absence of relaxin on collagen metabolism, using intact and ovariectomised pregnant animals.

\section{Materials and Methods}

\section{Animals}

These experiments were approved by the Institute's Animal Experimental Ethics Committee which adheres to the Australian Code of Practice for the care and use of animals for scientific purposes.

Eighty-three pregnant Sprague-Dawley rats of 240$300 \mathrm{~g}$ body weight were obtained from the Department of Zoology Animal Facility, University of Melbourne on day 7 of pregnancy. Females were placed with males on the night of proestrus, and the day on which sperm were identified in the vaginal lavage was designated day 1 of pregnancy. An additional 10 virgin (non-pregnant) rats obtained at 70 days of age were also used for this study. The animals were housed in a controlled environment and maintained on a $12 \mathrm{~h}$ light: $12 \mathrm{~h}$ darkness lighting schedule with access to laboratory chow (GR2+ rat pellets; Barastoc Stockfeeds Pty Ltd, Melbourne, Australia) and water. The animals were then allocated to the following groups.

Non-pregnant rats Non-pregnant (control) animals $(n=10)$ were killed under anaesthesia with carbon dioxide at 70 days of age. The pubic symphysis was removed and the pubic symphysial fibrocartilage (identified as the interpubic tissue that joins the pelvic bones together within the pelvic girdle) was collected, cleansed of any fat, muscle and bone, and weighed. Six of these pubic symphysial tissues were used for the determination of overall collagen content, and four other interpubic samples were used to determine collagen solubility and extractability.

Intact pregnant rats Adult rats (55-60 days of age) were mated as described above. Females found to be pregnant within 3 days of mating were used in these studies. On the morning of days 15, 18 and 21 of pregnancy, three groups of animals ( $n=11,11$ and 12 respectively) were killed under anaesthesia, and their pubic symphysial tissues dissected out and cleaned. Of these tissues, seven (day 15), seven (day 18) and six (day 21) samples were used to determine total collagen content, and four (day 15), four (day 18) and six (day 21) samples were used for the determination of collagen solubility and composition.

Ovariectomised pregnant rats treated with oestrogen and progesterone On day 9 of pregnancy, these rats $(n=20)$ were anaesthetised with Brietal sodium $(15 \mathrm{mg} / \mathrm{kg}$ body weight) before being bilaterally ovariectomised. A $0 \cdot 1 \mathrm{mg} 17 \beta$-oestradiol pellet which also contained $50 \mathrm{mg}$ progesterone (Innovative Research of America, Sarasota, FL, USA) was then implanted s.c. The pellets used in this study have previously been shown to release hormone from the cholesterol-methylcellulose- $\alpha$-lactose matrix over 21 days at a constant rate of $6 \mu \mathrm{g} /$ day oestradiol for a $0.5 \mathrm{mg}$ pellet (or approximately $1.2 \mu \mathrm{g} /$ day for the $0.1 \mathrm{mg}$ pellet) and $600 \mu \mathrm{g} /$ day for the progesterone preparation, in vitro (Barron et al. 1986). On the morning of days 18 and 21 , the interpubic tissue from these animals was collected and used to determine collagen content $(n=5$ and 5 respectively) and collagen solubility ( $n=5$ and 5 respectively). The doses of oestrogen and progesterone administered in these studies were based on the findings of Csapo \& Wiest (1969) (see Finn \& Porter 1975 for a review), who showed that administration of $0.5 \mathrm{mg}$ progesterone/ day alone to ovariectomised Sprague-Dawley rats was sufficient to maintain a $94 \%$ foetal survival rate and that the supplementation of this dose with $0 \cdot 1-1 \cdot 0 \mu \mathrm{g}$ oestrogen/day resulted in a $90-100 \%$ foetal survival rate.

\section{Ovariectomised pregnant rats treated with oestro-} gen, progesterone and relaxin On day 9, these rats $(n=5)$ were anaesthetised, bilaterally ovariectomised and subjected to s.c. implantation of the hormone pellets containing oestrogen and progesterone as described above. In addition, the animals were injected twice daily (s.c.) with purified recombinant human relaxin in citrate buffer $(10 \mathrm{mM}, \mathrm{pH} 5 \cdot 0)$ at $100 \mu \mathrm{g} / 0 \cdot 1 \mathrm{ml}$ per injection from day 10 to 13 and $200 \mu \mathrm{g} /$ injection from day 14 to 17 (with 
each dose being administered $12 \mathrm{~h}$ apart) as conducted by Downing \& Sherwood $(1985,1986)$. No signficant effects on any of the parameters measured had previously been observed in animals treated with vehicle alone when compared with measurements on non-pregnant rats (Samuel et al. 1996). On the morning of day 18, the interpubic tissues from these animals were collected and used to determine collagen content.

Intrapartum rats Interpubic tissues from a sixth group of pregnant rats $(n=7)$ were collected during labour after the rats had delivered at least two to three pups. These rats were monitored throughout late pregnancy and parturition by experienced animal facility technical staff. All seven tissues were used to determine total collagen content.

Postpartum rats Pubic symphysial tissues from a final two groups of rats $(n=17)$ were collected (i) less than $2 \mathrm{~h}$ after and (ii) approximately $24 \mathrm{~h}$ after the animals had given birth. Overall collagen content $(n=5$ and 4 respectively) and collagen solubility and composition $(n=4$ and 4 respectively) were then determined using the collected tissues.

\section{Determination of total collagen content}

Each pubic symphysial tissue sample from control and pregnant groups was trimmed of any excess tissue, blotted, weighed (wet weight) and lyophilised to dry weight. The length of each sample was measured before the tissues were defatted and analysed for total collagen content as described previously (Samuel et al. 1996). Triplicate aliquots from each sample were analysed for hydroxyproline content using a scaled-down version of the procedure described by Bergman \& Loxley (1963). Hydroxyproline concentrations were then converted to collagen content by multiplying by a factor of 6.94 (Gallop \& Paz 1975).

\section{Determination of soluble and insoluble collagen}

Collagens were serially extracted from diced pubic symphysial tissues as previously described (Bateman et al. 1986); all procedures were carried out at $4{ }^{\circ} \mathrm{C}$. Newly synthesised collagen was extracted with $0.05 \mathrm{M}$ Tris- $-\mathrm{HCl}$, $\mathrm{pH} 7 \cdot 5$, containing $0 \cdot 15 \mathrm{M} \mathrm{NaCl}$ and proteinase inhibitors (neutral salt-soluble fraction) for $24 \mathrm{~h}$; newly cross-linked collagen was then extracted from the neutral salt pellet (spun at 13000 r.p.m. for $45 \mathrm{~min}$ ) with an equal volume of $0.5 \mathrm{M}$ acetic acid (acetic acid-soluble fraction) for a further $24 \mathrm{~h}$. The extracts were centrifuged as above and the residues freeze-dried, weighed and subjected twice to limited pepsin digestion (enzyme:substrate ratio, 1:10) for $24 \mathrm{~h}$ to extract mature cross-linked matrix-forming collagens (pepsin-soluble fraction) (Cole et al. 1984). The hydroxyproline content of the extracts was measured, and the types of collagen present in the serially extracted fractions determined by PAGE.

\section{Cyanogen bromide $(\mathrm{CNBr})$ cleavage of fibrocartilage}

The pepsin-digested residues of the pubic symphysial tissues were dissolved in $100 \mathrm{mM} \mathrm{NH}_{4} \mathrm{CO}_{3}, \mathrm{pH} \mathrm{8} \cdot 0$, for $45 \mathrm{~min}$ to inactivate the pepsin, before being digested in 90\% formic acid containing $70 \mathrm{mg} \mathrm{CNBr}$. Cleavage was achieved by the method of Scott \& Veis (1976). Aliquots of each digest were assayed for hydroxyproline content, and the types of insoluble collagen present determined by electrophoretic analysis and comparison with purified collagen type-specific CNBr peptide standards.

\section{SDS-PAGE}

Soluble and pepsin-digested collagen chains were analysed on $5 \%(\mathrm{w} / \mathrm{v})$ acrylamide gels containing $3.5 \%(\mathrm{w} / \mathrm{v})$ acrylamide stacking gels, and insoluble collagen from the $\mathrm{CNBr}$ cleavage peptides were analysed on $12.5 \%(\mathrm{w} / \mathrm{v})$ acrylamide gels containing $4 \cdot 5 \%$ acrylamide stacking gels, as conducted previously (Samuel et al. 1996). The gels were stained overnight at $4{ }^{\circ} \mathrm{C}$ with $0 \cdot 1 \%(\mathrm{w} / \mathrm{v})$ Coomassie brilliant blue R-250 and destained with 30\% $(\mathrm{v} / \mathrm{v})$ methanol containing 7\% $(\mathrm{v} / \mathrm{v})$ acetic acid, before being dried and photographed.

Quantitative electrophoresis (densitometry) was used to determine the amounts of types I and II collagen as described by Chan \& Cole (1984). Gels of the CNBr cleavage peptides were scanned and the areas of the peaks determined in arbitrary units. Standard curves were used to plot the 'densitometry area' of the $\alpha 1$ (I)CB8 peptide (which was used as the marker peptide for type I collagen) and the $\alpha 1$ (II)CB10.5 peptide (which was used as the marker peptide for type II collagen) against the 'amount of collagen loaded onto the gels' (Chan \& Cole 1984); there was a linear relationship. Thus, by using the same type I and type II CNBr standards, which contained a known amount of $\mathrm{CNBr}$ collagen peptides, the area (of the peak) of these specific peptides was used to measure the specific collagen types present.

\section{Western blot analysis}

In order to confirm the presence of cartilage-specific type II collagen during pregnancy and parturition, nonpregnant and pregnant samples $(20 \%(\mathrm{v} / \mathrm{v})$ containing approximately $15-20 \mu \mathrm{g}$ protein) were electrophoresed as described previously with type-specific $\mathrm{CNBr}$ peptide standards (Samuel et al. 1996).

\section{Statistical analysis}

Differences between the groups were analysed using one-way ANOVA. The Bonferroni test was specifically used to compare the means of various parameters on 
Table 1 Effects of pregnancy and parturition on the mean \pm S.E.M. weight, length and water content of rat pubic symphyses

\begin{tabular}{|c|c|c|c|c|c|c|c|c|}
\hline & $n$ & $\begin{array}{l}\text { Wet weight } \\
(\mathrm{mg})\end{array}$ & $\%$ of NP & $\begin{array}{l}\text { Dry weight } \\
(\mathrm{mg})\end{array}$ & $\%$ of NP & $\begin{array}{l}\text { Length } \\
(\mathrm{mm})\end{array}$ & $\%$ of NP & $\begin{array}{l}\text { Water content } \\
(\%)\end{array}$ \\
\hline Non-pregnant & 10 & $28 \cdot 8 \pm 1 \cdot 2$ & - & $7 \cdot 9 \pm 0.5$ & - & $6 \cdot 7 \pm 0 \cdot 1$ & - & $72 \cdot 0 \pm 0 \cdot 9$ \\
\hline 15 days & 10 & $21 \cdot 9 \pm 1 \cdot 1^{*}$ & $76 \cdot 0$ & $4 \cdot 8 \pm 0 \cdot 4^{*}$ & $60 \cdot 8$ & $6 \cdot 9 \pm 0 \cdot 3$ & $103 \cdot 0$ & $78 \cdot 4 \pm 0 \cdot 9^{*}$ \\
\hline 18 days & 11 & $23 \cdot 7 \pm 1 \cdot 2$ & $82 \cdot 3$ & $4 \cdot 6 \pm 0 \cdot 3^{*}$ & $58 \cdot 2$ & $7 \cdot 0 \pm 0 \cdot 2$ & $104 \cdot 5$ & $80 \cdot 0 \pm 0 \cdot 6^{*}$ \\
\hline 21 days & 12 & $22 \cdot 5 \pm 0 \cdot 7^{*}$ & $78 \cdot 1$ & $5 \cdot 0 \pm 0 \cdot 3^{*}$ & $63 \cdot 3$ & $7 \cdot 1 \pm 0 \cdot 1$ & $106 \cdot 0$ & $78 \cdot 1 \pm 0 \cdot 9^{*}$ \\
\hline \multicolumn{9}{|c|}{ Ovariectomised pregnant } \\
\hline \multicolumn{9}{|c|}{ Ovariectomised pregnant + relaxin } \\
\hline 18 days & 5 & $19 \cdot 5 \pm 0 \cdot 7^{*}$ & $67 \cdot 7$ & $5 \cdot 1 \pm 0 \cdot 3^{*}$ & $64 \cdot 6$ & $6 \cdot 5 \pm 0 \cdot 2$ & $97 \cdot 0$ & $73 \cdot 8 \pm 0 \cdot 8$ \\
\hline Intrapartum & 7 & $16 \cdot 3 \pm 1 \cdot 1^{*}$ & $56 \cdot 6$ & $3 \cdot 4 \pm 0 \cdot 2^{*}$ & $43 \cdot 0$ & $6 \cdot 9 \pm 0 \cdot 1$ & $103 \cdot 0$ & $79 \cdot 3 \pm 0 \cdot 4^{*}$ \\
\hline \multicolumn{9}{|l|}{ Postpartum } \\
\hline$<2$ hours & 9 & $23 \cdot 5 \pm 1 \cdot 7$ & $81 \cdot 8$ & $5 \cdot 8 \pm 0 \cdot 1$ & $73 \cdot 4$ & $6 \cdot 9 \pm 0 \cdot 1$ & $103 \cdot 0$ & $75 \cdot 5 \pm 0 \cdot 5$ \\
\hline 24 hours & 8 & $32 \cdot 0 \pm 1 \cdot 1$ & $111 \cdot 1$ & $7 \cdot 5 \pm 0 \cdot 4$ & $94 \cdot 9$ & $7 \cdot 1 \pm 0 \cdot 1$ & $106 \cdot 0$ & $76 \cdot 6 \pm 0 \cdot 5$ \\
\hline
\end{tabular}

Water content is defined as the difference between the wet weight $(\mathrm{mg})$ and dry weight $(\mathrm{mg})$ and expressed as a percentage. ${ }^{*} P<0.05$ compared with the non-pregnant (control) group.

$\mathrm{NP}$, non-pregnant.

different days of gestation with those of non-pregnant measurements only. Changes in length, wet weight, dry weight, water content, collagen content and solubility were tested for significance, with $P<0 \cdot 05$ considered significant.

\section{Results}

Effect of pregnancy and parturition on the weight, length and water content of the interpubic tissue

Table 1 shows the changes in weight, length and water content of pubic symphysial tissues obtained during pregnancy and parturition as compared with non-pregnant tissues. During pregnancy, there was a significant $(P<0 \cdot 05)$ reduction in both the wet and dry weight of the interpubic tissue. Sample weights further decreased during parturition by approximately $57 \pm 3 \%$ and $43 \pm 3 \%$ respectively but had returned to non-pregnant values within $24 \mathrm{~h}$ of delivery. This reduction in tissue weight corresponded to a significant increase $(P<0 \cdot 05)$ in water content of samples derived from pregnant animals, from $72 \%$ of tissue composition in non-pregnant tissues to about $80 \%$ from day 15 of pregnancy right through until parturition. However, it was concluded that the dry weight (matrix) of the tissue had decreased in its own right. In the absence of relaxin, the weight and water contents of tissues obtained from ovariectomised animals supplemented with oestrogen and progesterone only were not significantly different from control samples. The weights of samples from animals treated with oestrogen, progesterone and relaxin (by injection) were significantly lower than non-pregnant measurements and mimicked values obtained during late pregnancy. The presence of relaxin, however, did not significantly influence the water content of the tissue. Furthermore, no significant changes were observed in the length of these samples during either pregnancy or parturition.

\section{Effect of pregnancy and parturition on collagen content of interpubic tissue}

Figure 1 shows the total collagen content of pubic symphysial tissues obtained during pregnancy and parturition, as well as from non-pregnant rats. The changes in collagen content were also compared with changes in serum relaxin levels (Sherwood \& Crnekovic 1979, Sherwood et al. 1980). Total collagen content $(2.64 \mathrm{mg})$ of interpubic tissues from non-pregnant (adult) animals represented approximately one-third of the dry weight of the tissue. By day 15 of pregnancy, the total amount of collagen had decreased $(P<0.05)$ by approximately $40 \%$ (from nonpregnant values) to $1.56 \mathrm{mg}$; it remained at this level until just before delivery. Collagen levels further decreased $(P<0 \cdot 05)$ during parturition to $1.39 \mathrm{mg}$, which represented a $47 \%$ reduction from non-pregnant values. The levels during parturition were not significantly different from those on days 15, 18 and 21 of pregnancy. Within $2 \mathrm{~h}$ of delivery, the overall collagen content had increased slightly $(1.62 \mathrm{mg})$, and then increased further to that of non-pregnant tissue within $24 \mathrm{~h}$ of delivery $(2.66 \mathrm{mg})$. In ovariectomised pregnant rats given oestrogen and progesterone, the absence of relaxin resulted in only a slight reduction in collagen levels. This reduction in collagen content was not significantly different from control values and was not as large as the reduction observed in intact pregnant samples. The administration of relaxin to these 

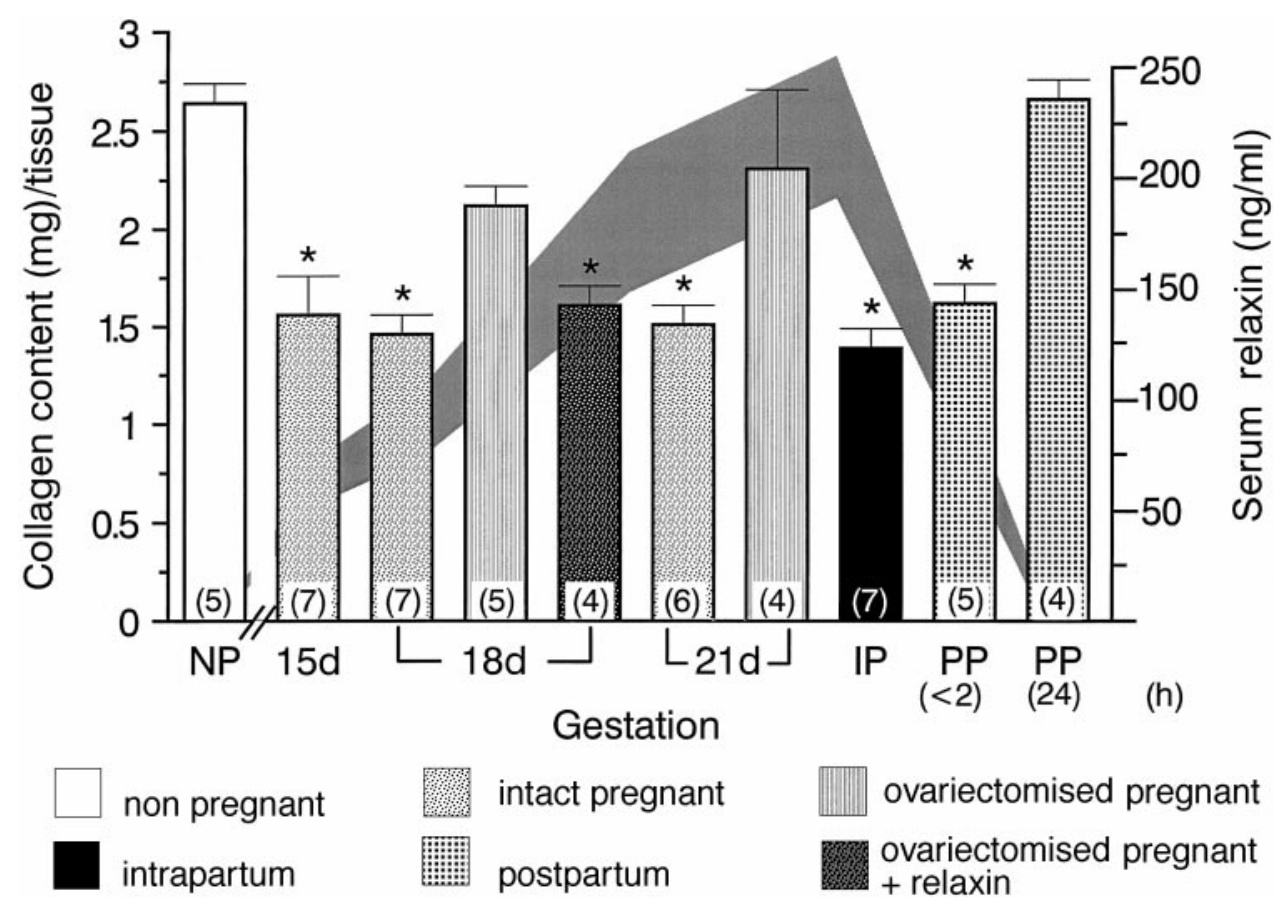

intact pregnant

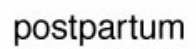

ovariectomised pregnant

\section{ovariectomised pregnant} + relaxin

Figure 1 Total collagen content (calculated from hydroxyproline values) of interpubic samples from non-pregnant (NP), intact pregnant (days 15, 18 and 21), ovariectomised pregnant (days 18 and 21), intrapartum (IP) and postpartum (PP) (within $2 \mathrm{~h}$ of delivery and $24 \mathrm{~h}$ after delivery) animals. The collagen levels were compared with previously measured (Sherwood \& Crnekovic 1979, Sherwood et al. 1980) serum relaxin levels (shaded curve in background). Numbers in parentheses represent number of samples. ${ }^{\star} P<0 \cdot 05$ when compared with NP values only.

ovariectomised animals induced a significant (39\%) decrease in collagen levels $(1.61 \mathrm{mg})$, such that they mimicked those measured during late pregnancy and parturition.

\section{Effect of pregnancy and parturition on collagen solubility in interpubic tissue}

To determine whether the reduced collagen levels were reflected in changes to collagen matrix maturation, total soluble and insoluble collagen were extracted from interpubic tissue during pregnancy and parturition as well as from non-pregnant animals (Fig. 2). Soluble collagen in non-pregnant tissues represented approximately $10 \%$ of the total collagen extracted, as indicated by extraction with the neutral salt buffer and acetic acid (which extracted the newly synthesised/uncross-linked and newly cross-linked collagens respectively). The remaining mature crosslinked insoluble collagen matrix required more extensive extraction by limited pepsin and $\mathrm{CNBr}$ digestion. During the second half of pregnancy (day 15 to parturition), there was a significant $(P<0 \cdot 05)$ decrease in the amount of soluble collagen, which was due to specific reduction of the newly cross-linked collagen fraction; this remained significantly lower than normal even up to $2 \mathrm{~h}$ after delivery. The combined mean levels of insoluble (pepsinand $\mathrm{CNBr}$-digested) collagen had also decreased during pregnancy, although not significantly, from almost $1600 \mu \mathrm{g}$ (controls) to a little under $1300 \mu \mathrm{g} 2 \mathrm{~h}$ after delivery. Both soluble and insoluble collagen levels had returned to control values within $24 \mathrm{~h}$ of delivery. The ratio of soluble to insoluble collagen during gestation remained at about 1:10. In the absence of the ovaries, and hence relaxin, the levels of soluble and insoluble collagen were not significantly different from non-pregnant values.

Effects of pregnancy and parturition on collagen composition in interpubic tissue

PAGE of the pepsin-digested collagen from non-pregnant (Fig. 3, lanes 2 and 3), pregnant (Fig. 3, lanes 4-9) and postpartum (Fig. 3, lanes 10-13) samples showed the presence of predominantly type I collagen $\alpha 1$ (I) and $\alpha 2(\mathrm{I})$ chains. The $\beta 11$ and $\beta 12$ components, which are covalently cross-linked $\alpha$-chain dimers, indicated that all samples were extensively cross-linked, confirming that pepsin digestion of the mature cross-linked collagen domains was required for efficient extraction. Furthermore, small amounts of the type $\mathrm{V}$ collagen $\alpha 1(\mathrm{~V})$ and $\alpha 2(\mathrm{~V})$ chains were identified throughout gestation. 


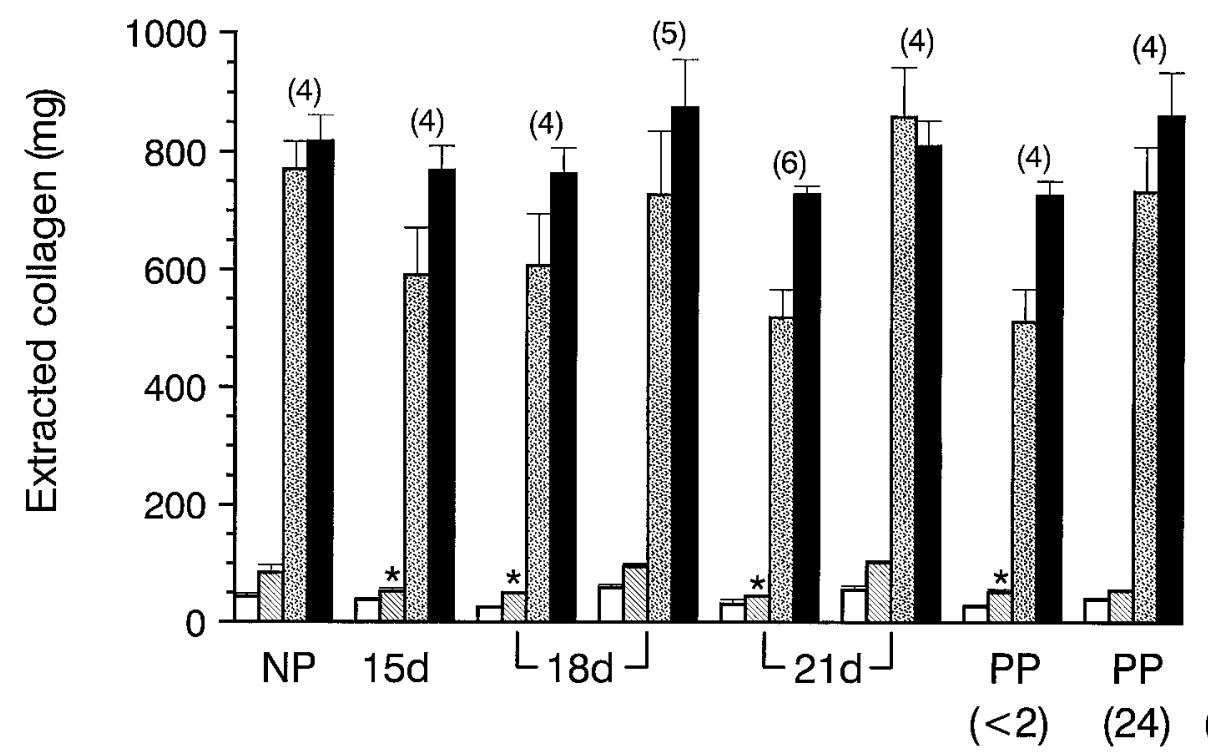

(h)

Figure 2 Extracted soluble and insoluble collagen from non-pregnant (NP), pregnant (days 15, 18 and 21 of pregnancy) and postpartum (PP) samples (within $2 \mathrm{~h}$ of delivery and $24 \mathrm{~h}$ after delivery). Numbers in parentheses represent number of samples. Soluble collagen was extracted with the neutral salt buffer (open bars) or acetic acid (hatched bars), and insoluble collagen was extracted by limited pepsin (stippled bars) or $\mathrm{CNBr}$ (solid bars) digestion of the leftover soluble collagen residue. The second set of bars for days 18 and 21 represent the soluble and insoluble collagen from interpubic tissue of ovariectomised pregnant rats supplemented with oestrogen and progesterone only. Individual tests were conducted for differences between the neutral salt-soluble, acetic acid-soluble, pepsin-digested insoluble and $\mathrm{CNBr}$ digested insoluble collagen at days 15, 18 and 21 of pregnancy as well as 2 and $24 \mathrm{~h}$ after parturition, as compared with their respective non-pregnant measurements. In addition, differences in the combined soluble (neutral salt- and acetic acid-soluble) and insoluble (pepsin- and CNBr-digested) collagen at the time points mentioned above were compared with their respective non-pregnant values: ${ }^{\star} P<0 \cdot 05$.

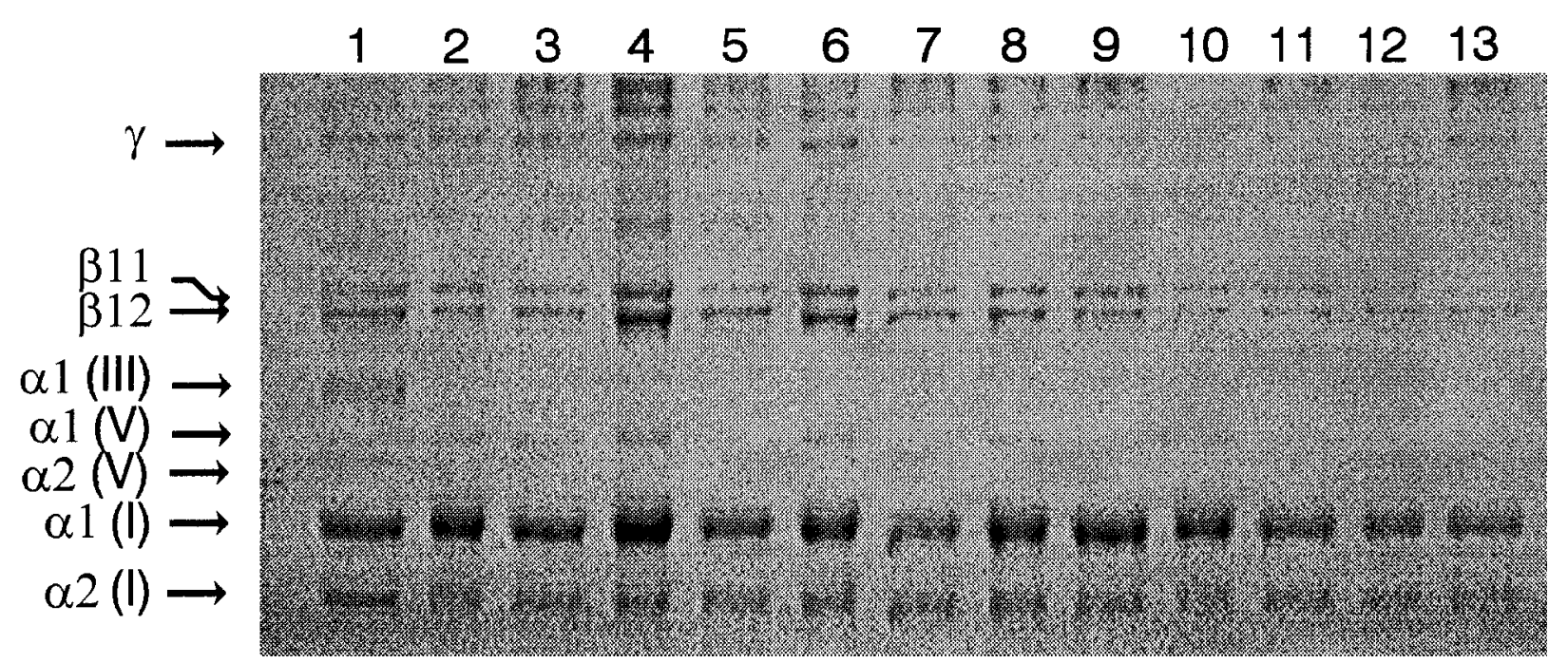

Figure 3 The pepsin-digested collagen, which represents approximately $60 \%$ of the total insoluble collagen, was analysed by SDS-PAGE, using delayed reduction of the disulphide bonds with $10 \% \beta$-mercaptoethanol. The samples consist of type I and III collagen standards (lane 1), and the collagen from two individual pepsin digests from a non-pregnant sample (lanes 2 and 3), from 15, 18 and 21 day pregnant samples (two lanes each, lanes 4-9 respectively) and from postpartum samples within $2 \mathrm{~h}$ of delivery (lanes 10 and 11 ) and $24 \mathrm{~h}$ after delivery (lanes 12 and 13). 


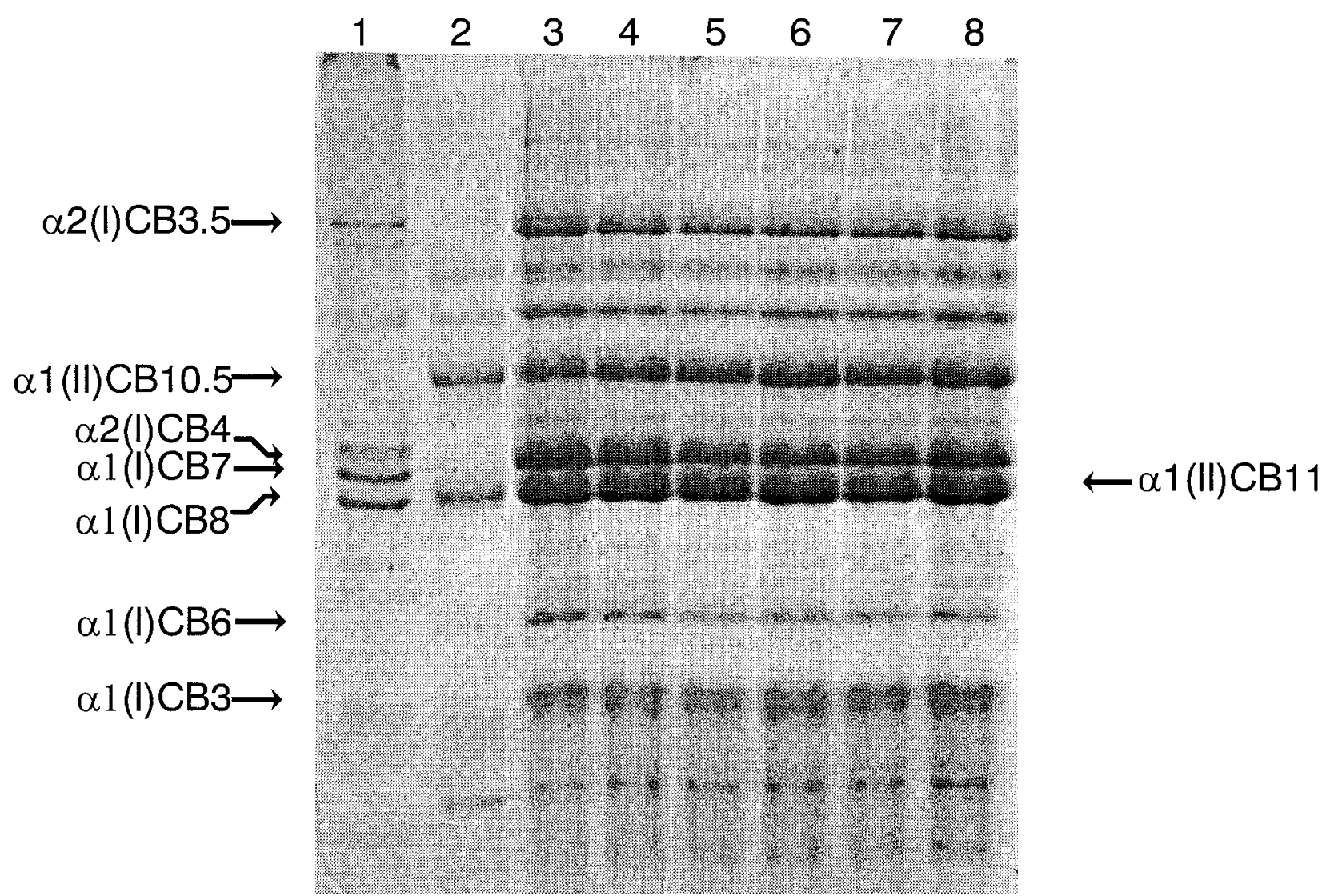

Figure 4 Type I and II collagen CNBr cleavage peptides analysed by gel electrophoresis. Samples consist of a type I-specific CNBr standard (lane 1), a type II-specific CNBr standard (lane 2) and CNBr-treated collagen from $20 \%(\mathrm{v} / \mathrm{v}$ ) pubic symphysial samples from a non-pregnant (lane 3), 15, 18 and 21 day pregnant (lanes 4-6) and postpartum (lanes 7 and 8) animals.

$\mathrm{CNBr}$ digests of the insoluble collagen residue (Fig. 4) confirmed the predominance of type I collagen (approx. $70-75 \%$ ) as the major collagenous component of the tissue, but further demonstrated the presence of type II collagen, as indicated by the presence of the $\alpha 1$ (II)CB10.5 and $\alpha 1$ (II)CB11 peptide fragments. The presence of type II collagen, which was observed throughout pregnancy, parturition and lactation, was confirmed by Western blot analysis (Fig. 5). Furthermore, quantitative electrophoresis (Fig. 4) of the collagen types confirmed that type II collagen represented approximately $25 \%$ of the total collagen in non-pregnant tissues. The intensity of the type II collagen bands remained at a constant level throughout pregnancy, indicating that the pubic symphysis remained a fibrocartilaginous tissue throughout gestation, as shown previously (Crelin \& Brightman 1957). Furthermore, as the composition of collagen did not change during pregnancy, it would appear that each of the collagen types were degraded at about the same rate.

\section{Discussion}

The results demonstrate that during pregnancy and particularly during parturition (delivery), the pubic symphysis of the rat undergoes a number of structural modifications, including a marked reduction in weight, which was primarily attributed to a significant reduction in overall collagen content. This was due to a significant reduction in the levels of soluble collagen as well as a small, statistically insignificant, decrease in insoluble collagen levels. Whereas distinct changes occurred in collagen content and solubility during pregnancy, parturition and lactation, the composition of the pubic symphysis, which included types I (approx. 70-75\%), II (approx. 25\%) and small amounts of type $\mathrm{V}$ collagen (1-2\%), remained unaltered. In addition, the observed changes in the extracellular matrix were associated with increased tissue water content during normal gestation, which reflected the overall hypotonicity of pregnancy and did not occur in ovariectomised animals treated with oestrogen and progesterone only. However, as the administration of relaxin to ovariectomised animals induced a significant decrease in tissue wet and dry weight, without significantly altering tissue water content, these data do not support the earlier proposal that relaxin is responsible for the changes in fluid balance observed during pregnancy (Weisinger et al. 1993). 


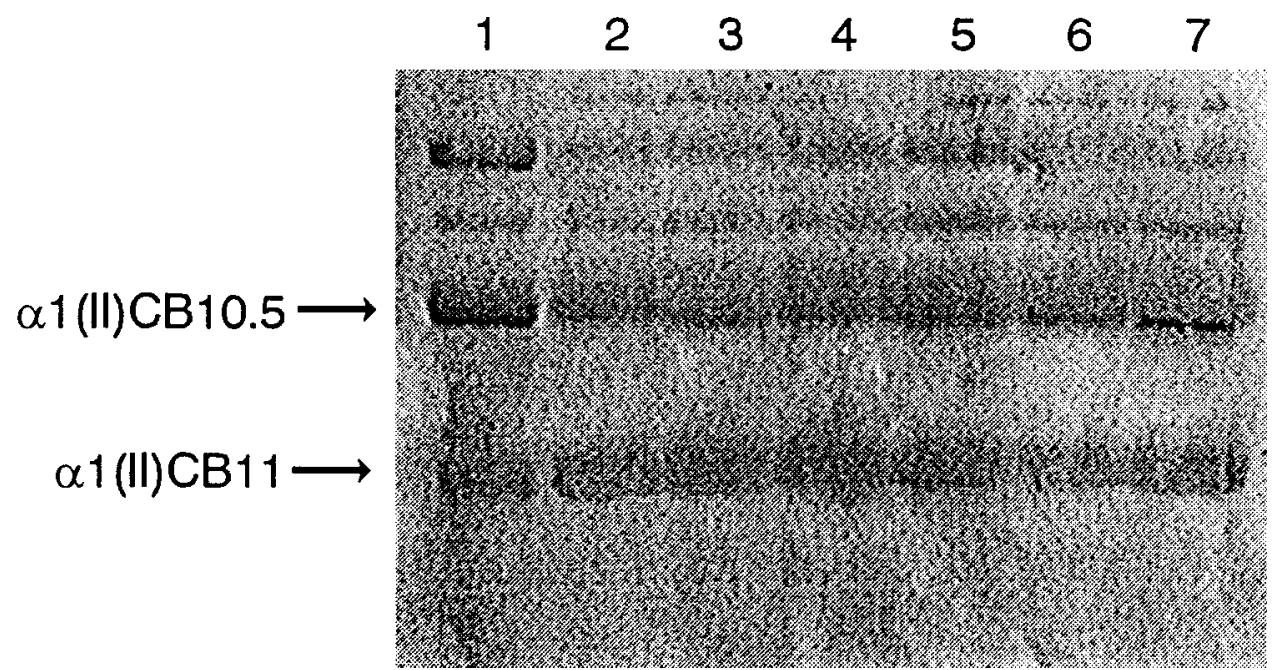

Figure 5 Confirmation of the presence of type II collagen by identification of the $\alpha 1$ (II)CB 10.5 and $\alpha 1$ (II)CB11 peptide fragments by Western blot analysis. Samples consist of a type II collagen-specific $\mathrm{CNBr}$ standard (lane 1) and type II collagen from interpubic tissue samples from a non-pregnant (lane 2), 15, 18 and 21 day pregnant (lanes 3-5 respectively) and postpartum (lanes 6 and 7) animals.

The significant decrease in collagen levels during pregnancy and parturition coincide with a rapid increase in serum relaxin levels during this time in the rat (Sherwood \& Crnekovic 1979, Sherwood et al. 1980), which suggests that the secreted hormone may play a significant role in remodelling collagen levels in preparation for parturition. Relaxin becomes detectable in the serum of pregnant rats by about day 10 of the approximately 23 day rat gestational period and then rapidly rises from day 20 until birth, with maximum levels ranging from 120 to $220 \mathrm{ng} / \mathrm{ml}$ approximately $24 \mathrm{~h}$ before birth. However, these levels rapidly decline soon afterwards, reaching a minimum of less than 5-10 ng/ml after parturition (Sherwood et al. 1980, 1983, Chrish et al. 1986), which coincides with a rapid increase in total collagen content.

These findings in pregnant animals can be compared with the effect of purified recombinant human relaxin on oestrogen-primed (non-pregnant) rats, in which the hormone stimulated the breakdown of two-thirds of the total collagen content in interpubic tissue (Samuel et al. 1996). The reduction in pubic symphysial collagen levels was somewhat different from the increase in collagen content that occurred during pregnancy and upon relaxin administration to the cervix (Downing \& Sherwood 1986) and uterus (Frieden \& Adams 1985) of the reproductive tract of the rat and other mammalian species (Wahl et al. 1977, Weiss et al. 1979). However, the net effect in all these species, regardless of tissue type, was a significant reduction in collagen concentration. These results confirm that the changes in collagen levels of interpubic tissue previously shown to be induced by the administration of relaxin (Samuel et al. 1996) are strikingly similar to those demonstrated to occur during pregnancy and parturition in the rat. Furthermore, in the absence of relaxin (in ovariectomised pregnant rats supplemented with oestrogen and progesterone), there was no significant effect on collagen levels when compared with those of nonpregnant tissues. The removal of relaxin may have caused the interpubic tissue to remain harder and more inextensible (inflexible) than it normally would be, thereby slowing down or preventing the passage of the young at term. Daily administration of relaxin to these ovariectomised animals significantly decreased the amount of collagen in the tissue, mimicking levels observed during the later stages of normal pregnancy. These findings therefore further suggest that the hormone is required to regulate extracellular matrix turnover in preparation for parturition, as they indicate that relaxin has an important regulatory role in collagen catabolism during gestation.

In conclusion, this investigation demonstrates that rat pubic symphysis undergoes rapid turnover of connective tissue during pregnancy and parturition specifically involving the breakdown of collagen. The modifications in collagen metabolism coincide with a surge in serum relaxin levels, which are highest from day 14 of pregnancy until just before delivery (Sherwood \& Crnekovic 1979, Sherwood et al. 1980). The reduction in collagen content may be attributed to collagen degradation through activation of the collagenolytic system (Too et al. 1984, 1986, Unemori \& Amento 1990), but the spectrum of collagen types remains unchanged throughout gestation. As the levels of relaxin decline during the later stages of parturition, the levels of collagen increase to those of nonpregnant tissue. These data provide further evidence that relaxin plays a key role in enabling successful parturition by regulating collagen catabolism during gestation in the rat. 


\section{Acknowledgements}

We thank Dr Danny Chan for providing the collagen standards, Mr Craig Thomson for expert technical assistance, Dr Donna Butkus for assistance with the use of the MCID (MicroComputer Image Device) and Dr Neale Yates for assistance with statistics. This study was supported by a block grant to the Howard Florey Institute from the National Health and Medical Research Council of Australia and grants from the Royal Children's Hospital Research Foundation.

\section{References}

Anderson MB \& Long JA 1978 Localization of relaxin in the pregnant rat: bioassay of tissue extracts and cell fractionation studies. Biology of Reproduction 18 110-117.

Anderson MB, Long JA \& Hayashida T 1975 Immunofluorescence studies on the localization of relaxin in the corpus luteum of the pregnant rat. Biology of Reproduction 13 499-504.

Barron WM, Schreiber J \& Lindheimer MD 1986 Effect of ovarian sex steroids on osmoregulation and vassopressin secretion in the rat. American Journal of Physiology 250 E352-E361.

Bateman JF, Chan D, Mascara T, Rogers JG \& Cole WG 1986 Collagen defects in lethal perinatal osteogensis imperfecta. Biochemical Journal 240 699-708.

Bateman JF, Lamande SR \& Ramshaw JAM 1996 Collagen superfamily. In Extracellular Matrix. Molecular Components and Interactions, vol 2, pp 22-67. Ed WD Comper. Amsterdam: Harwood Academic Publishers.

Bergman I \& Loxley R 1963 Two improved and simplified methods for the spectrophotometric determination of hydroxyproline. Analytical Chemistry 35 1961-1965.

Chan D \& Cole WG 1984 Quantitation of type I and III collagens using electrophoresis of alpha chains and cyanogen bromide peptides. Analytical Biochemistry 139 322-328.

Chrish JF, Soloff MS \& Shaw AR 1986 Changes in relaxin precursor mRNA levels in the rat ovary during pregnancy. Journal of Biological Chemistry 261 1909-1913.

Cole WG, Chan D, Hickey AJ \& Wilcken DEL 1984 Collagen composition of normal and myxomatous human mitral valves. Biochemical Journal 219 451-460.

Crelin ES \& Brightman MW 1957 The pelvis of the rat: its response to estrogen and relaxin. Anatomical Records 128 467-484.

Csapo AI \& Wiest WG 1969 An examination of the quantitative relationship between progesterone and the maintenance of pregnancy. Endocrinology 85 735-746.

Downing SJ \& Sherwood OD 1985 The physiological role of relaxin in the pregnant rat. I. The influence of relaxin on parturition. Endocrinology 116 1200-1205.

Downing SJ \& Sherwood OD 1986 The physiological role of relaxin in the pregnant rat. IV. The influence of relaxin on cervical collagen and glycosaminoglycans. Endocrinology 118 471-479.

Finn CA \& Porter DG 1975 Mechanical activity of hormonal control. In Reproductive Biology Handbooks: The Uterus, edn 1, pp 190-194. Eds CA Finn \& DG Porter. London: Elek Science.

Frieden EH \& Adams WC 1985 Stimulation of rat uterine collagen synthesis by relaxin. Proceedings of the Society of Experimental Biology and Medicine of the USA 180 39-43.

Gallop PM \& Paz MA 1975 Posttranslational protein modifications, with special attention to collagen and elastin. Physiological Reviews 55 418-487.

Golos TG, Weyhenmyer JA \& Sherwood OD 1984 Immunocytochemical localization of relaxin in the ovaries of pregnant rats. Biology of Reproduction 30 257-261.
Hall K 1956 An evaluation of the roles of oestrogen, progesterone and relaxin in producing relaxation of the symphysis pubis of the ovariectomized mouse, using the technique of metachromatic staining with toluidine blue. Journal of Endocrinology 13 384-393.

Prockop DJ \& Kivirikko KI 1995 Collagens: molecular biology, diseases and potentials for therapy. Annual Review of Biochemistry 64 403-434.

Ruth EB 1932 A study of the development of the mammalian pelvis. Anatomical Records 53 207-225.

Samuel CS, Butkus A, Coghlan JP \& Bateman JF 1996 The effect of relaxin on collagen metabolism in the nonpregnant rat pubic symphysis: the influence of estrogen and progesterone in regulating relaxin activity. Endocrinology 137 3884-3890.

Schwabe C, Steinetz B, Weiss G, Segaloff A, McDonald K, O’Byrne E, Hockman J, Carriere B \& Goldsmith L 1978 Relaxin. Recent Progress in Hormone Research 34 123-213.

Scott PG \& Veis A 1976 The cyanogen bromide peptides of bovine soluble and insoluble collagens. Connective Tissue Research $\mathbf{4}$ 107-116.

Sherwood OD 1994 Relaxin. In The Physiology of Reproduction, edn 2, pp 861-1009. Eds E Knobil \& JD Neill. New York: Raven Press.

Sherwood OD \& Crnekovic VE 1979 Development of a homologous radioimmunoassay for rat relaxin. Endocrinology 104 893-897.

Sherwood OD, Crnekovic VE, Gordon WL \& Rutherford JE 1980 Radioimmunoassay of relaxin throughout pregnancy and during parturition in the rat. Endocrinology 107 691-698.

Sherwood OD, Downing SJ, Golos TG, Gordon WL \& Tarbell MK 1983 Influence of light-dark cycle on antepartum serum relaxin and progesterone immunoactivity levels and on birth in the rat. Endocrinology 113 997-1003.

Sherwood OD, Downing SJ, Lao Guico-Lamm M, Hwang J-J, O’Day Bowman MB \& Fields PA 1993 The physiological effects of relaxin during pregnancy: studies in rats and pigs. Oxford Reviews of Reproductive Biology 15 143-189.

Steinetz BG, Manning JP, Butler M \& Beach V 1965 Relationships of growth hormone, steroids and relaxin in the transformation of pubic joint cartilage to ligament in hypophysectomised mice. Endocrinology 76 876-882.

Steinetz BG, O’Byrne EM, Butler MC \& Hickman LB 1983 Hormonal regulation of the connective tissue of the symphysis pubis. In Biology of Relaxin and Its Role in the Human, pp 71-92. Eds M Bigazzi, FC Greenwood \& F Gasparri. Amsterdam: Excerpta Medica.

Too CKL, Bryant-Greenwood GD \& Greenwood FC 1984 Relaxin increases the release of plasminogen activator, collagenase and proteoglycanase from rat granulosa cells in vitro. Endocrinology 115 1043-1050.

Too CKL, Kong JK, Greenwood FC \& Bryant-Greenwood GD 1986 The effect of oestrogen and relaxin on uterine and cervical enzymes: collagenase, proteoglycanase and $\beta$-glucuronidase. Acta Endocrinologica 111 394-403.

Unemori EN \& Amento EP 1990 Relaxin modulates synthesis and secretion of procollagenase by human dermal fibroblasts. Journal of Biological Chemistry 265 10681-10685.

Wahl LM, Blandau RJ \& Page RC 1977 Effect of hormones on collagen metabolism and collagenase activity in the pubic symphysis ligament of the guinea pig. Endocrinology 100 571-579.

Weisinger RS, Burns P, Eddie LW \& Wintour EM 1993 Relaxin alters the plasma osmolality-arginine vasopressin relationship in the rat. Journal of Endocrinology 137 505-510.

Weiss M, Nagelschmidt M \& Struck H 1979 Relaxin and collagen metabolism. Hormone and Metabolism Research 11 408-410.

Received 23 June 1997

Revised manuscript received 30 March 1998 Accepted 28 May 1998 